\title{
THE RIGHT TO BE FORGOTTEN: ISSUING A VOLUNTARY RECALL
}

\author{
R. George Wright
}

"'I have done that,' says my memory. 'I cannot have done that,' says my pride, and remains inexorable." ${ }^{\prime * *}$

\section{TABLE OF CONTENTS}

INTRODUCTION 401

I. PRIVACY, ANONYMITY, AND A RIGHT to BE FORGOTTEN:

BACKGROUND CONSIDERATIONS ...................................405

II. SOME IMPORTANT PRAGMATIC CONCERNS IN RIGHT TO BE

FORGOTTEN CONTEXTS..............................................410

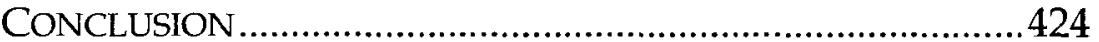

\section{INTRODUCTION}

Recently, the European Union Court of Justice recognized a socalled right to be forgotten. ${ }^{1}$ The right in question was officially declared to be fundamental in character. ${ }^{2}$ The contours of this right will

* Lawrence A. Jegen Professor of Law, Indiana University Robert H. McKinney School of Law.

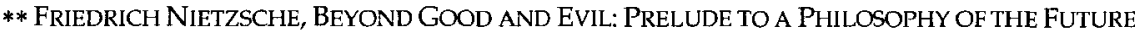
80 (Walter Kaufmann trans., Vintage 1989) (1886) (aphorism 68); see also Timothy Garton Ash, Bad Memories, ATLAS OF TRANSFORMATION, http://monumenttotransformation.org/ atlas-of-transformation $/ \mathrm{html} / \mathrm{m} /$ memory $/$ bad-memories-timothy-garton-ash.html (last visited Mar. 12, 2015).

1. Case C-131/12, Google Spain SL v. Agencia Española de Protección de Datos, Mario Costeja González (May 13, 2014), available at http:/ / curia.europa.eu (citing Council Directive 95/46, arts. 2, 4, 7-9, 14, 1995 O.J. (L 281) (EC)). The various national data protection agencies may order delinking, under specific name searches, to the data in question, if not the actual removal of the underlying posted data itself. $l d$. at 100 . The European Union is seeking a transnational framework for data protection law. See Proposal for a Regulation of the European Parliament and of the Council, COM (2012) 11 final (Jan. 25, 2012), available at http:/ / ec.europa.eu/justice/data-protection/document/review2012/com_2012_11_en.pdf [hereinafter EU General Data Protection Regulation]. The rubric of "data protection" in these cases is arguably a bit misleading. For ongoing commentary, see, for example, Essential Guide: EU Data Protection Regulation, COMPUTERWEEKLY.COM, www.computerweekly.com/guides/Essential-Guide-Whatthe-EU-Data-Protection-Regulation-changes-mean-to-you (last visited Apr. 2, 2015). For the specific language of forgetting, see for example, Google Spain, Case C-131/12, $1 \uparrow 20,89,91$.

2. See Google Spain, Case C-131/12, ๆ $101,91,97,99$. 
doubtlessly evolve, ${ }^{3}$ but for the moment Europe recognizes a personal right to ask internet search engine owners to remove links to third party web pages that appear following searches using one's name in the search query. ${ }^{4}$ The person requesting the delinking need not show prejudice, or the inaccuracy of the underlying post or web page. ${ }^{5} \mathrm{Ra}$ ther, the search engine operator is now legally required to consider whether the third party post or web page is, at the present time, "inadequate, irrelevant or no longer relevant, or excessive ...." ${ }^{6}$

The owner of the search engine in question, ${ }^{7}$ in making that crucial determination, must consider "all the circumstances of the case." ${ }^{8}$ The general presumption is that the interests of the data subject, or requesting party, should override "not only the economic interest of the

3. See EU General Data Protection Regulation, supra note 1; see also Convention for the Protection of Human Rights and Fundamental Freedoms art., 8, 10, Nov. 4, 1950, 213 U.N.T.S. 236.

4. See Google Spain, Case C-131/12, $1791-94$. It should go without saying that in any realistic form, the so-called "right to be forgotten" is not to be taken in any remotely literal sense. Id. The case law thus far focuses entirely upon specific events, actions, occurrences, status determinations, or other elements of a person's much broader life, personhood, or identity. See, e.g., id.

5. See id. |ㅔ 92-94, 96, 99.

6. Id. ๆ 94; see also id. ๆ 92-93.

7. These would include Google's search engines accommodating European countries, as well as parallel operations of such search engines as Bing and Yahoo. For a one-stop shopping option encompassing results from more than one search engine, see forget.me, https://forget.me (last visited Apr. 22, 2015); Adam Westlake, Bing, Yahoo Begin Accepting European 'Right to Be Forgotten' Requests, SLASHGEAR (November 29, 2014), http://www .slashgear.com/bing-yahoo-begin-accepting-european-right-to-be-forgotten-requests -29357778/. See also 2013 Search Engine Market By Country, RETURN ON Now, http://returnonnow.com/internet-marketing-resources/2013-search-engine-market-share

-by-country/ (last visited Apr. 22, 2015) (showing one incarnation of Google or another currently dominates the European market). Whether European law should also be binding on Google's broader global operations is currently controversial. See, e.g., Lisa Vaas, Google Fined for Not Taking Down "Right to be Forgotten" Links Worldwide, NAKEDSECURITY (Nov. 19, 2014), https://nakedsecurity.sophos.com/2014/11/19/google-fined-for-not-taking-down-right-to -be-forgotten-links-worldwide/; Sam Schechner \& Frances Robinson, EU Says Google Should Extend 'Right to be Forgotten' to '.com' Websites, WaLl ST. J. (Nov. 26, 2014, 10:59 am), http://online.wsj.com/news/article_email; Article 29 Working Party, EuR. COMMIssion (Jun. 8, 2013), http://ec.europa.eu/justice/data-protection/article-29/index_en.htm; Working Party, Guidelines on the Implementation of the Court of Justice of the European Union Judgment on "Google Spain and Inc v. Agencia Española de Protección de Datos and Mario Costeja González" C-131/12, WP 225 (Nov. 26, 2014) [hereinafter Article 29 Guidelines] (listing a "matrix" of thirteen typical factors addressing the merits of delinking requests, some with sub-parts, and none necessarily decisive).

8. Google Spain, Case C-131/12, I 94; Article 29 Guidelines, supra note 7. 
operator of the search engine but also the interest of the general public in finding that information upon a search relating to the data subject's name." ${ }^{\prime \prime}$ Crucially, though,

that would not be the case if it appeared, for particular reasons, such as the role played by the data subject in public life, that the interference with his fundamental rights is justified by the preponderant interest of the general public in having, on account of inclusion in the list of results, access to the information in question. ${ }^{10}$

The language of fundamental rights is thus cashed out largely in terms of a straightforward balancing test. ${ }^{11}$ In particular, the relevant fair balancing may

depend, in specific cases, on the nature of the information in question and its sensitivity for the data subject's private life and on the interest of the public in having that information, an interest which may vary, in particular, according to the role played by the data subject in public life. ${ }^{12}$

Interest in a broad so-called right to be forgotten is not confined to the European Union. ${ }^{13}$ Where it is eventually recognized, a presumably fundamental right to be forgotten may actually take different forms, reflecting local cultural differences. The scope of coverage and the strength of such a right are likely to vary as well. Already, the European Union has at least for the moment categorically distinguished between the obligations of search engine operators and those

9. Google Spain, Case C-131/12, ๆ 97; see also id. ๆๆ 99-100.

10. Id. ๆ 97.

11. See id. ๆ 81.

12. Id.; see also id. I 100. The result of such decisional balancing is then assumed to be administratively and judicially enforceable. See id. $\{82$.

13. See, e.g., Megumi Fujikawa, Google Suffers New Privacy Setback in Japan, WALL ST. J. (Oct. 14, 2014), http://www.wsj.com/articles/google-suffers-new-privacy-setback-in-japan -1412933523 (Tokyo District Court orders Google to remove search results regarding a man claiming a privacy invasion involving alleged danger to his life, as well as physical and psychological illness); Privacy Rights for California Minors in the Digital World, CAL. BUS. \& PrOF. CODE $\$ \$ 25580-25582$ (West 2015) (requiring website operators to remove material posted by a minor, though not by third parties, at the request of the minor); see also Edward Carter, Argentina's Right to be Forgotten, 27 EMORY INT'L L. REV. 23, 24-25 (2013). But see Argentina: Search Engines Are Not Liable Under Strict Liability Rules, DATA PRIVACY LAWS (Nov. 1, 2014), www.dataprivacylaws.com.ar/2014/11/01/467/. 
of underlying third party governmental or privately owned websites, ${ }^{14}$ including news aggregators. ${ }^{15}$ The proper strength of a fundamental right to be forgotten remains controversial even in official European circles. ${ }^{16}$

Given the evolving nature of the right to be forgotten, the focus below will not be on specific legal formulas, mechanisms, tests, or procedures. Instead, the focus will be on more basic underlying values, concerns, tendencies, experiences, patterns, risks, and costs. Controversial definitions of ideas such as privacy, autonomy, anonymity, and the public interest will be avoided as much as possible. The focus will instead be more practical. The argument below will rely not on dogmatic assertions about rights, but on a pragmatic sense of the inevitable basic problems in implementing such a right.

In the end, for pragmatic reasons, there should not be an adoption of a broad European-style legal right to be forgotten. Narrowly contextual particularized statutory and common law privacy, non-defamation, confidentiality, and emotional distress damages rightsalong with criminal expungement statutes - jointly provide a better alternative path. Narrowly focused holdings and statutes can readily be modified to address significant socio-economic class effects.

Any broad-sweeping legal right to be forgotten, beyond such narrow, particularized, context-sensitive accommodations, is ultimately likely, for practical reasons discussed throughout below, to be ill-advised. The superiority of a narrow, particularized, contextual, and pluralistic approach to a right to be forgotten flows from practically significant systematic biases and asymmetries between individuals seeking delinking or deletion of personal information on the one hand and information aggregators such as Google on the other. Some preliminary background considerations bearing upon this ultimate conclusion are introduced immediately below.

14. See Google Spain, Case C-131/12, ๆ 83 (distinguishing search engine sites from other, underlying, substantive websites); Article 29 Guidelines, supra note 7.

15. One largely U.S.-oriented traffic ranking of news websites lists, in descending order: Yahoo! News; Google News; HuffingtonPost; CNN; New York Times; Fox News; NBC News; Mail Online; Washington Post; The Guardian; WS]; ABCNews; BBC News; USA Today; and LA Times. Top 15 Most Popular News Websites, EBIZMBA (Apr. 2015), http://www .ebizmba.com/articles/news-websites. Of course, material arguably violating privacy rights could be posted on a wide range of websites not thought of as news-oriented.

16. See Jennifer Baker, Europe Mulls Weaker 'Right to Be Forgotten' Google Rule, THE REGISTER (Oct. 10, 2014, 5:27 PM), http://www.theregister.co.uk/2014/10/10/eu_ministers_google _right_to_be_forgotten_watered_down/; Vaas, supra note 7 . 


\section{Privacy, ANONYMITY, AND A RIGHT to BE ForgotTEN: BACKGROUND CONSIDERATIONS}

One preliminary problem is that the test of judicial protection for a right to be forgotten does not seem to match the dramatic rhetorical characterization of the right. The right in question has been exalted as a fundamental or human right. ${ }^{17}$ Yet the judicial test for upholding or restricting the right to be forgotten thus far seems to involve presumptions and a broad weighing and balancing of arguably relevant interests. ${ }^{18}$ Could a genuinely fundamental right really be traded off and overridden in this fashion?

A moment's reflection suggests, though, that rights we have long thought genuinely fundamental can indeed, in various contexts, be substantially limited in the name of the public interest. Consider, for example, the constitutional protection of freedom of speech, and in particular, speech on public streets and thoroughfares. The power of government to restrict speech on public streets, a traditional forum for public discussion, ${ }^{19}$ is said to be quite limited. ${ }^{20}$ The right to speak in public streets is in this sense basic and well established. ${ }^{21}$

A look at the typical purposes of public streets also suggests, however, common sense limitations on the relevant free speech right. At the very least, content neutral regulations of public street speech in the interests of traffic flow, and of safely avoiding distractions, collisions, hazards, and delays, may well be constitutionally permissible. ${ }^{22}$

The case of free speech in public streets thus suggests that we should not assume a distinctive problem with a fundamental right to be forgotten that can, in a broad range of contexts, be outweighed

17. See Google Spain, Case C-131/12, ๆ $81,91,97,99$.

18. See generally id.

19. See, e.g., McCullen v. Coakley, 134 S. Ct. 2518, 2528-29 (2014); Snyder v. Phelps, 131 S. Ct. 1207, 1218 (2011); Hurley v. Irish-Am. Gay, Lesbian and Bisexual Grp., 515 U.S. 557, 579 (1995); Frisby v. Schultz, 487 U.S. 474, 480-81 (1988); United States v. Grace, 461 U.S. 171, 180 (1983); Seattle Affiliate of the Oct. 22 Coal. to Stop Police Brutality v. City of Seattle, 550 F.3d 788, 796 (9th Cir. 2008) ("Street parades afford greater visibility to the marchers than parading down the sidewalk, and may also allow marchers to proceed abreast, march behind a horizontal banner, and more easily distribute materials to pedestrians on both sides of the street.").

20. See, e.g., McCullen, $134 \mathrm{~S}$. Ct. at 2529; Grace, 461 U.S. at 177.

21. Grace, 461 U.S. at 177.

22. See, e.g., McCullen, 134 S. Ct. at 2529 (citing Ward v. Rock Against Racism, 491 U.S. 781, 791 (1991)); Clark v. Cmty. for Creative Non-Violence, 468 U.S. 288, 293 (1984); Madsen v. Women's Health Ctr, Inc., 512 U.S. 753, 768 (1994); McTernan v. City of York, 564 F.3d 636, 65354 (3d Cir. 2009); People v. Barton, 8 N.Y.3d 70, 78 (2006) (upholding regulation of the speech of "individuals seeking handouts from occupants of motor vehicles on a public thoroughfare . .. thereby creating a hazard and slowing or snarling traffic."). 
merely by conflicting interests of general or particular sorts. If everything else were to fall into place, a right to be forgotten, as currently protected in Europe ${ }^{23}$ could by analogy still count as a genuinely fundamental right.

However, United States case law and statutory law do not, at least for the present, support any such generic, broad-sweeping right to be forgotten. The United States pattern is instead one of gradually accruing, narrow, particularized, contextually sensitive protections of various loosely related rights, along with statutory protections of particular sorts, in their particular contexts. ${ }^{24}$ If a formal label for this narrower, more modest United States approach is absolutely necessary, we could borrow the phrase "disjoint incrementalism." ${ }^{25}$ Thus far, United States' law has typically avoided European-style expansive, comprehensive grand theory in this regard.

The high water mark of any relatively broad-sweeping United States approach is the 1931 California Appellate Court decision in Melvin v. Reid. ${ }^{26}$ The opinion in Melvin is exceptionally moralistic in its language, rationale, and tone. ${ }^{27}$ The case involved a movie that relied not merely on presumably scandalous prior incidents somehow preserved in a public record, but on the defendant's use of the plaintiff-appellant's name in connection with those prior incidents, after she had allegedly rehabilitated herself some eight years before the movie in question. ${ }^{28}$ The Melvin court thus opined that

[t] he use of appellant's true name in connection with the incidents of her life [involving prostitution] in the plot and advertisements was unnecessary and indelicate, and a willful and wanton disregard of that charity which should actuate us in our social intercourse, and which should keep us from unnecessarily holding another up to ... scorn .... ${ }^{29}$

23. See supra notes 1, 3 and accompanying text.

24. David Braybrooke \& Charles E. Lindblom, A STRATEgy of DeCision: Policy EvaluATION AS A SOCIAL PROCESS ch. 5 (1970).

25. Id.; see also Charles E. Lindblom, The Science of "Mudding Through," 19 PuB. ADMIN. Rev. 79,81 (1959) (contrasting "Rational-Comprehensive (Root)" policy analysis methods with more modest, narrower, incrementalist "Successive Limited Comparisons (Branch)" methods).

26. 297 P. 91 (Cal. Dist. Ct. App. 1931).

27. See generally id.

28. See id. at 91.

29. Id. at 93 . 
In broad terms, the Melvin court declared that "[a]ny person living a life of rectitude has that right to happiness which includes a freedom from unnecessary attacks on his character, social standing, or reputation." ${ }^{30}$ Only a bit more contextually, the Melvin court then concluded that

the publication ... of the unsavory incidents in the past life of appellant after she had reformed, coupled with her true name, was not justified by any standard of morals or ethics known to us, and was a direct invasion of her inalienable right guaranteed to her by our Constitution, to pursue and obtain happiness. Whether we call this a right of privacy or give it any other name is immaterial .... ${ }^{31}$

It cannot be said with certainty whether the reasoning of Melvin would extend to serious criminal activity, breaches of trust, public figures, matters of public concern, more recent rehabilitations, or different means of dissemination, including government publications. No issue of the completeness or incompleteness of the plaintiff's rehabilitation arose in Melvin, as the case was decided on the basis of the defendant's motion to dismiss. ${ }^{32}$ Based on the broad-sweeping language in Melvin, ${ }^{33}$ one might imagine that most or all of these above categories would indeed fall within the scope of Melvin.

Interestingly, though, the court's own initial summary of the law of privacy makes a case for excluding cases of public figures, ${ }^{34}$ matters of (continuing) public interest ${ }^{35}$ matters of public record, ${ }^{36}$ oral statements, ${ }^{37}$ and perhaps even not-for-profit speech. ${ }^{38}$ The later United

30. Id.

31. Id.

32. See id.

33. See id.

34. See id.

35. See id. Query whether the public figure versus private figure distinction should be absorbed into the more relevant, though often difficult, inquiry into whether the material in question addresses a matter of public interest and concern. See sources cited infra, note 73.

36. See Melvin, 297 P. at 93 . The public record versus privacy conflict was addressed in Cox Broad. Corp. v. Cohn, 420 U.S. 469, 495 (1975) ("Public records by their very nature are of interest to those concerned with the administration of government, and a public benefit is performed by the reporting of the true contents of the records by the media."). See also Florida Star v. B.J.F., 491 U.S. 524, 526 (1989) (holding that Florida law that punished newspapers for printing sensitive but publicly available information violated the First Amendment).

37. See Cox Broad. Corp., 420 U.S. at 495.

38. As we shall see, a number of these considerations are often thought to be relevant to, if not dispositive of, right to be forgotten cases. See infra Part II. 
States case law establishes that disowning one's prior public figure status may not be practical in some cases, and more important for our purposes, will often trigger a fact-sensitive, circumstance-based, contextual inquiry by the court. ${ }^{39}$ The passage of time, even along with one's good faith efforts, may not suffice to change one's public figure status, or the nature and weight of any public interest at stake. ${ }^{40}$

The themes of incrementalism, particularity, context, and circumstance are more useful in accounting for the scope and limits of the most important contemporary United States privacy statutes. The already more or less contextualized federal Freedom of Information Act, ${ }^{41}$ for example, itself has a number of further contextualized exemptions, ${ }^{42}$ and these exemptions from disclosure are typically narrowly construed. ${ }^{43}$ The narrow construction rule applies even to some of the most privacy-focused Freedom of Information Act cases, ${ }^{44}$ if less so to others, ${ }^{45}$ depending, again, upon circumstances and the changing weight of the relevant contextualized interests. ${ }^{46}$ The similarly contextualized Privacy Act of 1974 also involves numerous

39. See Sidis v. F-R Pub. Corp., 113 F.2d 806, 807-09 (2d Cir. 1940) ("[e]veryone will agree that at some point the public interest in obtaining information becomes dominant over the individual's desire for privacy"). The Sidis court clearly engages in a contextualized inquiry. See id. at 809 . For philosophical explorations of some distinctive forms of contextualism and particularism in moral theory, see, respectively, MARK TIMMONS, MORALITY WITHOUT FOUNDATIONS: A DEFENSE OF ETHICAL CONTEXTUALISM (2004); MORAL PARTICULARISM (Brad Hooker \& Margaret Olivia Little eds., 2001). On the Sidis case in particular, see Samantha Barbas, The Sidis Case and the Origins of Modern Privacy Law, 36 COLUM. J.L. \& ARTS 21 (2012).

40. See Sidis, 113 F.2d at 807-09; Contemporary Mission, Inc. v. New York Times, 842 F.2d 616, 619 (2d Cir. 1988); Mitre Sports Int'l, Ltd. v. Home Box Office, 22 F.Supp.3d 240, 251 (S.D.N.Y. 2014); Jones v. New Haven Register, Inc., 763 A.2d 1097, 1100 (2000) (" $[\mathrm{t}]$ he Supreme Court of the United States has not yet decided 'whether or when an individual who was once a public figure may lose that status by the passage of time'") (quoting Wolston v. Reader's Digest Ass'n, Inc., 443 U.S. 157, 166 n.7 (1979)).

41. See 5 U.S.C. $\$ 552(2009)$.

42. See id.

43. See Milner v. Dep't of Navy, 131 S. Ct. 1259, 1265 (2011); Dep't of Interior v. Klamath Water Users Protective Ass'n, 532 U.S. 1, 8 (2001); FBI v. Abrahmson, 456 U.S. 615, 630 (1982); Citizens for Responsibility \& Ethics in Washington v. United States, 746 F.3d 1082, 1088 (D.C. Cir. 2014).

44. See FOIA Exemption 6, 5 U.S.C. $\$ 552(b)(6)$, recognizing relevant public interests and adopting a "clearly unwarranted" invasion of personal privacy standard; see, e.g., Yonemoto v. Dep't of Veterans Affairs, 686 F.3d 681 (9th Cir. 2012) (discussing Freedom of Information Act exemptions).

45. See FOIA Exemption 7(c), 5 U.S.C. $§ 552(b)(7)(c)$, adopting an expansive “unwarranted invasion" of privacy standard regarding law enforcement records access; see, e.g., Nat'l Archives \& Records Admin. v. Favish, 541 U.S. 157, 171 (2003) (" $[\mathrm{t}]$ he term 'unwarranted' requires us to balance the family's privacy interest against the public interest in disclosure"); Dep't of Justice v. Reporters Comm. for Freedom of Press, 489 U.S. 749 (1989).

46. See sources cited supra note 45. 
thoughtful exemptions, beyond its limited scope of application only to most federal governmental agencies. ${ }^{47}$

At the state level, the various arrest and conviction expungement statutes seek - again within discrete, particular, limited contexts - to accommodate certain narrow privacy interests. ${ }^{48}$ Expungement statutes promote relatively limited privacy interests in limited contexts, and they can clearly be modified in the future to be more socio-economically just in their impact. United States courts have been unwilling to read anything like a European-style general right to be forgotten into typical criminal expungement statutes. ${ }^{49}$ As a leading case concluded, "[a]lthough our expungement statute generally permits a person whose record has been expunged to misrepresent his past, it does not alter the metaphysical truth of his past, nor does it impose a regime of silence on those who know the truth. ${ }^{\prime 50}$ Doubtless web pages, posts, and search engine results are more cheaply and undetectably revised than are items in paper archives and bound volumes. But as the court in question crucially observed, expungement statutes are "not intended to create an Orwellian scheme, whereby previously published information-long maintained in official records-now becomes beyond the reach of public discourse on penalty of a defamation [or privacy] action." ${ }^{\prime 51}$

On the basis of these background considerations, then, let us consider some of the crucial issues associated with a purported right to

47. See Pub. L. No. 93-579, 88 Stat. 1896 (codified at 5 U.S.C. $\S \S 552 a(a)(8)(B)$, (a)(8)(j-k)). For an analogously relatively limited, qualified, and nuanced student record privacy statute in another discrete context, see the Family Educational Rights and Privacy Act of 1974, Pub. L. No. 90-247, 88 Stat. 571 (codified at 20 U.S.C. \$1232g et seq.); see also Owasso Indep. School Dist. v. Falvo, 534 U.S. 426 (2002) (construing the Family Educational Rights and Privacy Act of 1974). For statutory privacy rights and exemptions in yet another comparatively discrete context, see the Health Insurance Portability and Accountability Act of 1996, Pub. L. No. 104-191, 110 Stat. 1936 (codified at 42 U.S.C. $\$ \$ 201$ et seq.).

48. See, e.g., Fla. Stat. Ann. \$943.0585 (West 2014) (specifying the discrete scope of coverage and exceptions). For convenient access to a broader range of state expungement statutes, see Expungement and Criminal Records: State-Specific Information, FINDLAW, http://criminal findlaw.com/expungement/expungement-and-criminal-records-state-specific-information .html (last visited Mar. 19, 2015).

49. See generally, Expungement and Criminal Records: State-Specific Information, supra note 48.

50. G.D. v. Kenny, 15 A.3d 300, 316 (N.J. 2011).

51. Id. at 319 (same result under "false light" claim). For further discussion, see Martin v. Hearst Corp., No. 3:12CV1023(MPS), 2013 WL 5310165, at *6 (D. Conn. Aug. 5, 2013). For the Orwellian "memory hole" reference, see for example, Catherine Rampell, America: The Land of No Second Chance, CHICAGo TRIBUNE (Nov. 5, 2014), http://www.chicagotribune.com/news/ opinion/commentary/ct-second-chances-for-elites-only-perspec-1196-20141105-story.html (raising the question of the effects of a broad right to be forgotten on different socio-economic classes). 
be forgotten, not primarily at the level of competing definitions and the abstract clash of rights, and interests, but at a more pragmatic, investigative, realistic, operational level.

\section{SOME IMPORTANT PRAGMATIC CONCERNS IN RIGHT TO BE FORGOTTEN CONTEXTS}

In some fields of study, carefully defining relevant terms and systematically analyzing those terms and their relationships yields substantial advances in understanding. ${ }^{52}$ Unfortunately, in the general context of a purported legal right to be forgotten, this is not likely to be the case. Conceptual analysis, short of a more pragmatic investigation informed by sensible judgments, will only carry us so far.

While privacy rights are often considered fundamental, ${ }^{53}$ the idea of privacy itself has proven to be not merely controversial, but enduringly elusive ${ }^{54}$ To illustrate some remarkably basic conceptual uncertainties, consider the claim that:

the more one thinks about privacy, the less confident one can be that privacy is a distinctly moral desideratum, as opposed to a largely prudential one, when it is anything more than a matter of a widely shared taste. .. . [O]ur interest in privacy is mainly a matter of taste and prudence. ${ }^{55}$

In contrast, the idea of anonymity is used in fewer divergent senses than that of privacy, but it does not seem to be of consistently positive-let alone overridingly positive-value. One scholar argues that anonymity "is not reducible to privacy, liberty and autonomy, security, or secrecy, but is distinguished from them by its hallmark trait of dissociability." ${ }^{56}$ Dissociability, in turn, involves the morally ambiguous ability to prevent others from knowing us as we really are, ${ }^{57}$ and naturally inspires in us a certain ambivalence. While anonymity

52. See, e.g., Euclid, Elements (Dana Densmore ed., Thomas L. Heath trans., Green Lion Press 2002) (300 B.C.).

53. See James Q. Whitman, The Two Western Cultures of Privacy: Dignity Versus Liberty, 113 YALE L.J. 1151, 1153 (2004).

54. See id. at 1153 ("honest advocates of privacy protections are forced to admit that the concept of privacy is embarrassingly difficult to define") (citing, inter alia William M. Beaney, The Right to Privacy and American Law, 31 LAW \& CONTEMP. PROBS. 253, 255 (1966)); Robert C. Post, Three Concepts of Privacy, 89 Geo. L.J. 2087 (2001).

55. Alexander Rosenberg, As a Matter of Taste and Right, in THE RIGHT TO PRIVACY 68, 68 (Ellen Frankel Paul, Fred D. Miller \& Jeffrey Paul eds., 2000).

56. Julie Ponesse, The Ties That Blind: Conceptualizing Anonymity, 45 J. SOC. PHIL. 304, 317 (2014).

57. See id. 
can certainly allow us "to protect ourselves in morally permissible ways, ${ }^{\prime 58}$ as in the case of Alcoholics Anonymous membership, ${ }^{59}$ it also "permits a range of moral vices, for it also shields us from accountability for wrongdoing." ${ }^{60}$ We naturally have a similar ambivalence about the related idea of concealment. Concealment involves, often positively, "reticence and nonacknowledgement," ${ }^{161}$ as well as, and often more negatively, manipulation, and "secrecy and deception." ${ }^{\prime \prime 2}$

Our understandable ambivalence as to the value of anonymity, self-concealment, and privacy more generally, ${ }^{63}$ is however, ultimately based less in definitional and conceptual issues than in important pragmatic concerns and experiences. ${ }^{64}$ Mere assertion of a right to privacy "may prevail for a time, but only so long as the benefits that it opposes are small." ${ }^{\prime 5}$ The most decisive considerations for and against any supposed right to be forgotten are thus, in the long run, more likely to be of a pragmatic, experiential character.

58. Steve Matthews, Anonymity and the Social Self, 47 AM. PHIL. Q. 351, 352 (2010). It has analogously been argued that privacy in general "is an essential part of human flourishing or wellbeing." Adam D. Moore, Privacy: Its Meaning and Value, 40 AM. PHIL. Q. 215, 223 (2003).

59. See Matthews, supra note 58 , at 352.

60. Id.

61. Thomas Nagel, Concealment and Exposure, 27 PHIL. \& PUB. AFF. 3,4 (1998); RICHARD A. POSNER, THE ECONOMICS OF JUSTICE chs. 9-10 (2007) (discussing privacy as being left alone versus privacy as enhancing opportunities for self-interested manipulation and selective disclosure); Richard A. Posner, The Right of Privacy, 12 GA. L. REV. 393, 395 (1978) (" [S]ocial, like business, dealings present opportunities for exploitation through misrepresentation"); David Friedman, Privacy and Technology, in THE RIGHT TO PRIVACY, supra note 55, at $189 \mathrm{n.5}$ (noting that borrowers with no past bankruptcies will be better off with weak or effectively waivable privacy and non-disclosure rights).

62. Nagel, supra note 61 , at 4 .

63. See R. George Wright, Some Reasons For Our Ambivalence About the Value of Privacy, 22 B.U. PUB. INT. L.J. 45 (2013) and the surveys cited therein. For a snapshot of United States popular ambivalence as to more specific dimensions of privacy, including the removal of links or online posts and the freedom of speech or of the press, along with grounds and rationales, see H.O. Maycotte, 'America's Right to Be Forgotten' Fight Heats Up, ForbES (Sept. 30, 2014, 9:51 AM), http:/ /www.forbes.com/sites/ homaycotte/2014/09/30/americas-right-to-be-forgotten -fight-heats-up/.

64. See, e.g., Lloyd L. Weinreb, The Right to Privacy, in THE RIGHT TO PRIVACY, supra note 55, at 44 .

65. Id. Thus, "those who would defend privacy as we know it will have to provide a convincing account of the human good that overshadows the material rewards that are offered in its place. It will not be easy." Id. We should clarify that there is no reason to believe that all of the pragmatic costs of pursuing a right to be forgotten will be material or financial in character. 
At a pragmatic level, our attitudes toward the value of remembering and forgetting particular life incidents are mixed. ${ }^{66}$ We enjoy inspiring stories of those persons who capitalize on an unexpected second chance. ${ }^{67}$ But we also value the opportunity to meaningfully inform ourselves about strangers upon whom we might wish to rely, ${ }^{68}$ including via a convenient and inexpensive search of internet records. ${ }^{69}$ The practical value of such internet records reflects not only their accuracy, but their realistic thoroughness and availability. Some intentional deletions, after all, could unexpectedly turn out to be deceptive, misleading, ${ }^{70}$ and costly to perhaps unforeseen persons. $^{71}$

The problem of the costs to various other persons of a right to be forgotten remains important. This is true even if the entities making a removal decision take seriously the distinctions between currently relevant information, irrelevant information, or supposedly outdated information, and between matters of ongoing public interest and those that do not thus qualify. ${ }^{72}$ As a leading expert rightly observed, "the concepts of relevance and of public interest [are] both very slippery." ${ }^{13}$

66. The great novelist and short story writer Jorge Luis Borges points out that at the level of the individual most directly concerned, literal forgetting is necessary for meaningful thought. See Jorge Luis Borges, Funes the Memorious, available at www.srs-pr.com/ literature/borges-funes.pdf; see also ANNE GALLOWAY, COLLECTIVE REMEMBERING AND THE IMPORTANCE OF FORGETTING: A CRITICAL DESIGN CHALLENGE (2006), available at http://purselipsquarejaw.org/papers/galloway_chi2006.pdf (citing Jorge Luis Borges, Funes the Memorious). Memories and meanings from the past may also be excessively discounted, rather than discounted insufficiently. See DAvid GROSS, LOST TIME: ON REMEMBERING AND FORGETTING IN LATE MODERN CULTURE 152 (2000).

67. See, e.g., Michael G. SAntos, EARning FreEdom: CONQUERING A 45 YEAR PRison Term (2013).

68. See generally, REPUTATION.COM, www.reputation.com/reputationdefender (last visited Mar. 31, 2015) (promoting programs for reputation control).

69. See id.; see also Whitney Hackathorne, Speak Now or Forever Hold Your Tweets, THE HARRIS POLL (June 3, 2010), http://www.harrisinteractive.com/NewsRoom/HarrisPolls/tabid/ 447/mid/1508/articleId/403/ctl/ReadCustom\%20Default/Default.aspx.

70. See ITT Cont'l Baking Co. v. FTC, 532 F.2d 207, 219 (2d Cir. 1976) (discussing deception and misleading in the Federal Trade Commission regulatory context).

71. See sources cited supra note 61.

72. See Case C-131/12, Google Spain SL v. Agencia Española de Protección de Datos, Mario Costeja González, (May 13, 2014), available at http://curia.europa.eu (citing Council Directive 95/46, arts. 2, 4, 7-9, 14, 1995 O.J. (L 281) (EC) II 81, 85, 92-94, 97 (May 13, 2014), available at http:/ / curia.europa.eu).

73. Luciano Floridi, Google's Privacy Ethics Tour of Europe: A Complex Balancing Act, THE GuARDIAN (Sept. 16, 2014) http://www.theguardian.com/technology/2014/sep/16/googles -european-privacy-ethics-tour; see also LUCIANO FLORIDI, THE FOURTH REVOLUTION: HOW THE 
Consider, for example, the inevitable difficulties in trying to assess the continuing relevance of some assumedly accurate item of information. To even begin to guess about such questions, the decision maker would need to know something of the particular contexts and circumstances in which the information in question might, in the future, be sought. Such matters are typically not entirely known even to the party requesting the deletion of the link or web posting in question. The relevant insights, of whatever quality, are instead widely dispersed across time and space, and among many parties, ${ }^{74}$ most of whom will have no notice of the removal request and costly alternative access, if any, to the removed information. ${ }^{75}$

INFOSPHERE IS RESHAPING HUMAN REALITY ch. 5 (2014) (extending treatment of the social implications of emerging information technologies). For a sense of the difficulties in managing the distinction between public interests and merely private interests in some related contexts, see Stephen Allred, From Connick to Confusion: The Struggle to Define Speech on Matters of Public Concern, 64 IND. L.J. 43, 45, 47, 54 (1988); Cynthia L. Estlund, Speech on Matters of Public Concern: The Perils of an Emerging First Amendment Category, 59 GEO. WASH. L. REV. 1, 8-12 (1990); Robert C. Post, The Constitutional Concept of Public Discourse: Outrageous Opinion, Democratic Deliberation, and Hustler Magazine v. Falwell, 103 HARV. L. REV. 603, 615 (1990); Mark Strasser, What's It to You: The First Amendment and Matters of Public Concern, 77 MO. L. REV. 1083, 1086-89 (2012); R. George Wright, Speech on Matters of Public Interest and Concern, 37 DEPAUL L. REV. 27, 29-30 (1987).

74. For the standard discussion of the broad diffusion of relevant present knowledge throughout much of the community, see Friedrich August von Hayek, The Use of Knowledge in Society, 35 AM. ECON. REV. 519, 519 (1945) ("the knowledge of the circumstances of which we must make use never exists in concentrated or integrated form, but solely as the dispersed bits of incomplete and frequently contradictory knowledge which all the separate individuals possess."); see also Friedrich August von Hayek, The Pretence of Knowledge, 79 AM. ECON. REv. 3, 7 (1974).

75. Some search engines, including Google, may controversially provide some limited notice that otherwise includable search results have been omitted due to privacy law concerns, see for example, Roberta Holland, Court Data Ruling Causing Host of Compliance Issues, COMPLIANCE WEEK (Aug. 6, 2014), http://www.complianceweek.com/blogs/global-glimpses/ court-data-ruling-causing-host-of-compliance-issues; Schechner \& Robinson, supra note 7 (describing official EU view of routine deletion notifications as potentially undermining the effectiveness of the right's implementation). Some websites, including that of the BBC, may then choose to post a list of their own articles subjected to delinking, as they are informed of such delinkings by Google. See, e.g., Dave Lee, BBC to Publish 'Right to Be Forgotten' Removals List, BBC NEws (Oct. 17, 2014), http://www.bbc.com/news/technology-29658085. If a market for deleted results or underlying web pages, posts, or articles develops, we can expect search engines and specialized websites to respond. See Claire Cain Miller, It's Not as Simple as Asking to 'Be Forgotten' by Google, N.Y. TIMES (May 17, 2014), http://www.nytimes.com/2014/ 05/27/upshot/its-not-as-simple-as-asking-to-be-forgotten-by-google.html. There has already been some limited movement in this direction. See, e.g., HIDDEN FROM GOOGLE, http:/ / hiddenfromgoogle.afaqtariq.com/ (last visited Apr. 23, 2015); Caitlin Dewey, The Web Site that Remembers Things Google Forgot, WASH. POST (July 16, 2014), http://www .washingtonpost.com/news/the-intersect/wp/2014/07/16/the-web-site-that-remembers -things-google-forgot/; see also, ARE THEY SAFE, http://aretheysafe.co.uk (last visited Apr. 23, 2015) (offering background checks among the available services in the United Kingdom). Any 
The crucial problem, though, is not that the information provided by anyone requesting delinking or deletion will commonly be merely "incomplete." or another, to reasonable contest and debate. ${ }^{77}$ The more significant problem is that removal and delinking decisions affecting those partly unpredictable future circumstances will commonly be made at the request of an exceptionally interested party, whose version of the relevant circumstances will typically be unchallenged by knowledgeable persons, if not simply presented ex parte. ${ }^{78}$ The potential for systematic bias and distortions of various sorts in largely ex parte presentations with obvious and substantial information asymmetries is clear. ${ }^{79}$

The largely ex parte nature of most deletion requests, in which the personally incentivized requester has both greater information access and strong self-interest considerations, is not the only relevant asymmetry. ${ }^{80}$ Consider the rare deletion requests that proceed to some higher administrative or even judicial level. The majority of such requests will presumably be appeals of a denied deletion request. Lack of symmetry in taking the initiative will thus be built into the appeals

practical limits on the geographic or jurisdictional scope of privacy laws and decisions may of course impair their enforceability.

76. See European Union Committee, Eu Data Protection law: A 'Right to be ForgotTEN?' Second Report, 2014-15, H.L. 40 at 11, available at http://www.publications .parliament.uk/pa/ld201415/ldselect/ldeucom/40/40.pdf.

77. See sources cited infra note 73; see also Daniel J. Solove, Introduction: Privacy Self-Management and the Consent Dilemma, 126 HARV. L. REV. 1879, 1881 (2013) ("It is virtually impossible for people to weigh the costs and benefits of revealing information ... . without an understanding of the potential downstream uses....").

78. See, e.g., Agence Fr. Presse, Google Is Having Trouble Determining the Legitimacy of Europe's 91,000 'Right to Be Forgotten' Requests, BUS. INSIDER (Aug. 1, 2014, 6:31 AM), http://www.businessinsider.com/google-is-having-trouble-determining-the-legitimacy-of

-europes-91000-right-to-be-forgotten-requests-2014-8 ("Even if requesters provide us with accurate information, they understandably may avoid presenting facts that are not in their favor.").

79. Consider for example, the case of a removal request by someone who is known by local insiders to be an ambitious likely future candidate for office. See Nancy Scola, Designing 'The Right to Be Forgotten,' WASH. POST (Aug. 4, 2014), http://www.washingtonpost.com/ blogs/the-switch/wp/2014/08/04/designing-the-right-to-be-forgotten/ (also noting, parenthetically, that compliance costs may disproportionately burden emerging or start-up technologies, thereby amounting to a legal barrier to entry by new competitors). For some theoretical background on the importance of information asymmetries more broadly, see generally George A. Akerlof, The Market For "Lemons": Quality Uncertainty and the Market Mechanism, 84 Q.J. ECON. 488 (1970). Socially harmful information asymmetries can often be reduced by the free and open use of the internet. For an introduction, see STEVEN D. LEVITT \& STEPHEN J. DUBNER, FREAKONOMICS 61-62 (2006).

80. See LEVITT \& DUBNER, supra note 79, at 61-64. 
system. In most cases, if no broader principle is at stake, the realistic financial incentives of the parties are likely to be asymmetric as well, especially where the requester, but not the search engine owners, seeks money damages or attorneys' fees.

Information that has been publicly available on the internet is both more easily removed, and at the same time, paradoxically, often harder to entirely remove, ${ }^{81}$ as opposed to former technologies. ${ }^{82} \mathrm{We}$ naturally identify and sympathize with those persons who continue to suffer the consequences of prior indiscretions, or even non-culpable acts and associations. But broad-sweeping legal rules and regimes in this area, even if they encourage some form of attempted interest balancing, are nevertheless ill-advised.

A broad interest balancing approach at least recognizes that "people's decisions about their own privacy affect society, not just themselves." ${ }^{13}$ Ideally, though, privacy decision makers should not confine themselves to holding a mental picture of a living, breathing personal requester against a merely faceless, disembodied, unsympathetic, abstract "society." Societal interests must indeed be considered, in the best available ways. But it is also useful to at least try to think concretely and particularly of those now anonymous, faceless persons who might, at some point in the future, unfairly suffer from the unavailability, or from the availability only at a high cost, of the deleted information. ${ }^{84}$

Nor, as alluded to above, ${ }^{85}$ can we count on the more or less good faith judgment of those persons who are motivated to seek a deletion or delinking. We should instead expect systematic, though unintended, biases in such requests and presentations. This is not primarily a matter of conscious deception by requesters, but of familiar psychological overall tendencies and patterns in broad populations.

81. See sources cited supra note 74; Jeffrey Rosen, The Right to Be Forgotten, 64 STAN. L. REV. ONLINE 88, 88, available at http://www.stanfordlawreview.org/sites/default/files/ online/topics/64-SLRO-88.pdf ("It is very hard to escape your past on the Internet now that every photo, status update, and tweet lives forever in the cloud."). Note the possible long-term cultural spur to developing early the classical Aristotelian virtue of prudence. See infra note 91.

82. Consider, anecdotally, that East German decisions to pulp books on political grounds did not necessarily preclude the publication of West German editions of the same books. See ROBERT DARNTON, CENSORS AT WORK: HOW STATES SHAPED LITERATURE 217-18 (2014).

83. Solove, supra note 77 , at 1881 .

84. Any decision-making process that contrasts an identified present person with the vague interests of abstract society risks systematic bias through our common misuse of what are called availability heuristics. For the relevant pioneering work, see generally Amos Tversky \& Daniel Kahneman, Availability: A Heuristic For Judging Frequency and Probability, 5 COGNITIVE PSYCHOL. 207 (1973).

85. See supra note 78 . 
Consider, to begin with, Nietzsche's aphorism serving as the epigram above: "I have done that,' says my memory. 'I cannot have done that,' says my pride, and remains inexorable." ${ }^{\text {" }}$ Alternatively, but equally relevant to our context, consider Adam Smith's observation that "[i]t is so disagreeable to think ill of ourselves that we often purposely turn away our view from those circumstances which might render that judgment unfavorable." ${ }^{17}$

One leading contemporary privacy theorist has publicly wondered whether interest in a broad right to be forgotten "may be a sign that we are tired of confronting our past mistakes and responsibilities." 88 Contemporary social science would suggest that typically, we are not far removed from self-serving, ${ }^{89}$ if not self-deluded, attitudes. ${ }^{90}$ The desire, however, to erase negative elements of our public past is often more understandable than fully justified.

The tendency to be systematically biased judges in our own case seems pervasive and well-established. ${ }^{91}$ This poses a distinctively severe problem for broad, and largely ex parte, right to be forgotten statutes and other broad privacy rules. The problem exists whether

86. See supra note ${ }^{\star *}$ and accompanying text.

87. ADAM SMITH, THE THEORY OF MORAL SENTIMENTS pt. III, ch. 4, I 4 (David D. Raphael \& Alec L. Macfie eds., Oxford Univ. Press 1976) (1790) (quoted in Harvey Mitchell, "The Mysterious Veil of Self-Delusion" in Adam Smith's Theory of Moral Sentiments, 20 AM. SOC'Y EIGHTEENTH-CENTURY STUD. 405, 405 (1987)) (discussing the common tendency toward self-deception).

88. Floridi, supra note 73.

89. See LA Rochefoucauld, Maxims NO. 2, at 37 (Leonard Tancock trans., Penguin 1959) (1665) ("Is]elf-love is the greatest flatterer of all"); see also id. No. 56, at 44 ("[i]n order to succeed in the world people do their utmost to appear successful").

90. See, e.g., William von Hippel \& Robert Trivers, The Evolution and Psychology of Self-Deception, 34 BEHAV. \& BRAIN SCl. 1 (2011) (discussing the evolutionary survival and selection advantages of some capacities for (self-serving) self-delusion, especially as communicated to other persons).

91. See ARISTOTLE, EudEMIAN ETHICs bk. II ch. 5, at 22 (Anthony Kenny trans., Oxford Univ. Press 2011) ("our nature from the outset is not in every case equidistant from the mean; we are ... excessively keen on self-indulgence"); see also ARISTOTLE, NICOMACHEAN ETHICS bk. III ch. 2, at 74 (Christopher Rowe trans., Oxford Univ. Press 2002) (1893) ("self-indulgence would seem to be justly a matter of reproach"). For some possible social implications, see the discussion in JOHN LOCKE, SECOND TREATISE OF GOVERNMENT \$ 13, in TwO TREATISES OF GOVERNMENT (Peter Laslett ed., Cambridge Univ. Press 1988) (1690). By way of contrast, consider that the dystopian ruler Mustapha Mond exalts "[s]elf-indulgence up to the very limits imposed by hygiene and economics. Otherwise the wheels stop turning." ALDOUS HUXLEY, BRAVE NEW WORLD 237 (Harcourt Perennial Modern Classics 1998) (1932). For an expression of concern as to the likely character of professional or willing official censors, see John Milton, Areopagitica, Speech to the Parlament of England (1644), available at https://www.dartmouth .edu/ $\sim$ milton/reading_room/areopagitica/text.shtml. 
or not the incidences of self-indulgence and self-absorption are worsening over time. ${ }^{92}$ For our purposes, any form and degree of narcissism, ${ }^{93}$ as well as any sense of personal entitlement, ${ }^{94}$ may reinforce what is professionally known as attribution bias and an arbitrary minimization of personal responsibility. ${ }^{95}$ Attribution bias simply refers to the idea that "[p]eople are more likely to attribute positive events to themselves but dismiss negative events as attributable to other causes." ${ }^{\prime 96}$

Nor can people-including those seeking removal of personal information from the internet-be counted on to recognize their own self-serving biases regarding the causes, consequences, and possible continuing relevance of their prior acts. Generally, people are better at detecting self-serving attributional bias in other persons-when they have sufficient unbiased information to do so - than they are in

92. See Claude Fischer, Are We More Self-Absorbed Than Previous Generations, Or Just More Self-Aware?, THE BERKELEY BLOG (June 26, 2014), http://blogs.berkeley.edu/2014/06/26/are -we-more-self-absorbed-than-previous-generations-or-more-self-aware/.

93. See Jean M. TWENGE \& W. Keith Campbell, The Narcissism Epidemic: Living in the AGE OF ENTITLEMENT 283 (2009) ("[t]rue humility is a strength: the ability to see or evaluate yourself accurately and without defensiveness"); CHRISTOPHER LASCH, THE CULTURE OF NARCISSISM: AMERICAN LIFE IN AN AGE OF DIMINISHING EXPECTATIONS 13-16 (rev. ed., 1991); Jean M. Twenge \& Joshua D. Foster, Birth Cohort Increases in Narcissistic Personality Traits Among American College Students, 1982-2009, 1 SOC. PSYCHOL. \& PERSONALITY SCI. 99, 100 (2010). For a conflicting analysis as to whether some forms of narcissism are becoming more common or more severe over time, see generally Jeffrey Jensen Arnett, The Evidence for Generation We and Against Generation Me, 1 EMERGING ADULTHOOD 5 (2013).

94. See, e.g. JEAN M. TWENGE, GENERATION ME: WHY TODAY'S YOUNG AMERICANS ARE MORE CONFIDENT, ASSERTIVE, ENTITLED - AND MORE MISERABLE THAN EVER BEFORE (2006); W. Keith Campbell, et al., Psychological Entitlement: Interpersonal Consequences and Validation of a Self-Respect Measure, 83 J. PERSONALITY ASSESSMENT 29, 29 (2004) ("[p]sychological entitlement has a pervasive and largely unconstructive impact on social behavior"); Lauren N. Pryor, et al., $A$ Comparison of the Psychological Entitlement Scale and the Narcissistic Personality Inventory's Entitlement Scale: Relations With General Personality Traits and Personality Disorders, J. OF PERSONALITY ASSESSMENT 517, 517 (2008) (entitlement as a dimension of both narcissistic personality disorder and trait narcissism).

95. Amy H. Mezulis, et al., Is There a Universal Positivity Bias in Attributions? A Meta-Analytic Review of Individual, Developmental, and Cultural Differences in the Self-Serving Attributional Bias, 130 PSYCHOL. BULL. 711, 711 (2004); see also Martin D. Coleman, Emotion and the Self-Serving Bias, 30 CURRENT PSYCHIATRY 345, 345 (2011) ("[t]he self-serving bias is revealed in the behavioral tendency to take credit for personal success but to deny responsibility for personal failure" which protects self-esteem); Miron Zuckerman, Attribution of Success and Failure Revisited, Or: The Motivational Bias Is Alive and Well in Attribution Theory, 47 J. PERSONALITY \& SOC. PSYCHOL. 245 (1979).

96. Mezulis, supra note 95, at 711 . 
the case of their own judgments. ${ }^{97}$ As several experts have jointly concluded, "people readily detect or infer a wide variety of biases in others while denying such biases in themselves." ${ }^{\prime 8}$

These attributional biases thus jointly operate to systemically skew our own sense of responsibility for our own past actions. Again, the argument is not that these biases have been historically increasing. Instead, the argument is that such biases tend to outweigh any counter-biases tending in the opposing direction. If we then think of what we have done as largely externally controlled or otherwise, ${ }^{99}$ on any imaginable theory, not fully our own responsibility, ${ }_{1}^{100}$ we may more uninhibitedly seek removal of unfavorable information, and the stories we tell about our prior acts may also reflect these biases.

The biases energizing us to obscure unfavorable elements of our past and to shade their telling to others are linked to a superficial kind of self-forgiveness. ${ }^{101}$ But there is also a deeper and more valuable sort of self-forgiveness that is instead linked to the appropriate acceptance of responsibility, rather than to its denial or minimization. ${ }^{102}$ This deeper sort of self-forgiveness requires that we acknowledge and accept genuinely appropriate responsibility, rather than deny, contest,

97. See generally Emily Pronin, Thomas Gilovich \& Lee Ross, Objectivity in the Eye of the Beholder: Divergent Perceptions of Bias in Self Versus Others, 111 PSYCHOL. REV. 781, 781 (2004) [hereinafter Pronin, Objectivity]; Emily Pronin, Daniel Y. Lin \& Lee Ross, The Bias Blind Spot: Perceptions of Bias in Self Versus Others, 28 PERSONALITY \& SOC. PSYCHOL. BULL. 369, 369 (2002); Emily Pronin, How We See Ourselves and How We See Others, 320 SCI. 1177, 1179 (2008).

98. Pronin, Objectivity, supra note 97, at 781.

99. See generally Julian B. Rotter, Internal Versus External Locus of Control of Reinforcement: A Case History of a Variable, 45 AM. PSYCHOL. 489 (1990) (discussing expectancies of internal versus external control of reinforcement); Julian B. Rotter, Some Problems and Misconceptions Related to the Construct of Internal Versus External Control of Reinforcement, 43 J. CONSULTING \& CLINICAL PSYCHOL. 56 (1975) (discussing internal versus external control of reinforcement as a personality variable); Julian B. Rotter, Generalized Expectancies for Internal Versus External Control of Reinforcement, 80 PSYCHOL. MONOGRAPHS: GENERAL \& APPLIED 1 (1966) (summarizing experiments that examine group differences based on whether reinforcement was seen as internal or external).

100. For merely one kind of impulse toward a denial of one's personal responsibility, see Patrick Gosling, Maxime Denizeau \& Dominique Oberle, Denial of Responsibility: A New Mode of Dissonance Reduction, 90 J. PERSONALITY \& SOC. PSYCHOL. 722, 730 (2006) ("We believe that denial of responsibility reduces dissonance through a mechanism of disengagement from one's own behavior."). More broadly, more controversially, and more speculatively, see Joseph Epstein, The Perpetual Adolescent, WEEKLY STANDARD (March 15, 2004), http://www .weeklystandard.com/Content/Public/Articles/000/000/003/825grtdi.asp.

101. See Peter Strelan, Who Forgives Others, Themselves, and Situations? The Roles of Narcissism, Guilt, Self-Esteem, and Agreeableness, 42 PERSONALITY \& INDIVIDUAL DiFFERENCES 259, 259-60 (2007).

102. See id. at 260 (" $[\mathrm{t}]$ aking responsibility is a key aspect of self-forgiveness, distinguishing it from the related process of the self-serving bias, where individuals take responsibility for positive outcomes but not negative outcomes"). 
minimize, or evade such responsibility. ${ }^{103}$ This personal acceptance should encompass not merely the unfavorable event itself, but the record of the event as available to the public, as well as one's own relevant conduct after the fact.

Encouraging realistic attitudes toward one's own past actions and other outcomes is generally in the public interest. But, the socially valuable maturity and integrity manifested in such attitudes suggests the ways in which the person most immediately concerned may also be genuinely better off, morally or practically, as well. ${ }^{104}$ A number of the classic philosophers have gone so far as to disdain any concern for one's broad public reputation, as distinct from one's actual underlying virtues. ${ }^{105}$

It is of course difficult to say what price persons generally pay, fairly or unfairly, in practical terms when only our recommended narrower, particularized, contextual legal remedies are available for what persons take to be reputational harms. Persons are clearly sometimes capable of change over time, whether as a matter of character, or of circumstance. ${ }^{106}$ Some sort of collective acknowledgement and legal accommodation of this possibility of favorable change certainly seems both familiar and appropriate. ${ }^{107}$

103. See, e.g., Julie H. Hall \& Frank D. Fincham, Self-Forgiveness: The Stepchild of Forgiveness Research, 24 J. SOC. \& CLINICAL PSYCHOL. 621, 622 (2005) (genuine self-forgiveness as becoming "decreasingly motivated to avoid stimuli associated with the offense," and in our cases, more broadly, the underlying unfavorable event and its report).

104. See id. Consider, in particular, the eventual forthrightness of Jean Valjean: "From what motive . . did this convict come and say: I am convict? . . The motive is strange. It is from honor." VICTOR HuGO, Les MISERABLES 1394 (Lee Fahnestock \& Norman MacAfee trans., Signet 1987) (1862).

105. See, e.g., Plato, Euthyphro, Apology, Crito (F.J. Church trans., Pearson 1987) ( 399 B.C.); EPICTETUS, THE ENCHIRIDION $\S$ xxxiii, at 32 (Thomas W. Higginson trans., Bobbs-Merrill 1948) ( 140) ("If anyone . . speaks ill of you, do not make excuses . . but answer: 'He was ignorant of my other faults, else he would not have mentioned these alone."'); MARCUS AURELIUS, MEDITATIONS book 4, §3, at 64 (Maxwell Staniforth trans., Penguin 1964) ( 167) (“ [h]e who ignores what his neighbor is ... thinking, and cares only that his own actions should be just and godly, is greatly the gainer in time and ease"); BOETHIUS, THE CONSOLATION OF PHILOSOPHY ch. 4, at 13 (P.G. Walsh trans., Oxford Univ. Press 1999) ( 524) (initially lamenting his loss of reputation).

106. See, e.g., Dawinder Sidhu, We Don't Need a "Right to Be Forgotten." We Need a Right to Evolve, NEW REPUBLIC (Nov. 7, 2014), http://www.newrepublic.com/article/120181/america -shouldnt-even-need-right-be-forgotten.

107. See id. (endorsing a non-legally enforceable social norm favoring a "right to a dynamic identity"). For a brief articulation of a more extreme view minimizing the role of distinctive, stable, robust, character traits, see Gilbert Harman, The Nonexistence of Character Traits, PRINCETON UNIVERSITY (Sept. 6. 2002), available at http://www.princeton.edu/ harman/ Papers/Virresp.html. 
The broader public, however, also has some grounds for not casually assuming nearly universal or dramatic character change for the better as person's age. One scholar has argued:

personality is . . relatively enduring over time. In fact, the levels of consistency in personality traits are ... higher than phenomena such as income, blood pressure, and cholesterol levels, and substantially higher than psychological ideas such as happiness and self-esteem. ${ }^{108}$

It remains true that however small the magnitude of the change, ${ }^{109}$ people can indeed become more responsible, more caring, and more conscientious, particularly as they enter and transition through adulthood ${ }^{110}$ These results accord with the popular view that adolescents may "settle down," mature, and take on responsibility as they move into and through adulthood. The social science evidence suggests that we do tend to be reasonably realistic about the likely direction of change in other people's personality over time and tend to be logical about discounting their earlier behaviors to at least some degree. ${ }^{111}$

Finally, consider some of the most practical dimensions of the distinct further problem of paternalism. A broad, murky rule mandating a right to be forgotten of one sort or another would in a real sense count as paternalistic. ${ }^{112}$ Of course, to the extent that such a broad

108. Brent Roberts, Personality, Continuity and Change, PsYCHOLOGY TIMES (Winter, 2010), available at http://www.psychology.illinois.edu/alumni/news/newsletter/documents/ PsychTimesWinter2010.pdf.

109. See, e.g., Avshalom Caspi \& Brent W. Roberts, Personality Development Across the Life Course: The Argument for Change and Continuity, 12 PSYCHOL. INQUIRY 49, 61 (2001).

110. See id.; Dan P. McAdams \& Bradley D. Olson, Personality Development: Continuity and Change Over the Life Course, 61 ANNUAL REV. PSYCHOL. 517, 532 (2010); Brent W. Roberts et al., Patterns of Mean-Level Change in Personality Traits Across the Life Course: A Meta-Analysis of Longitudinal Studies, 132 PsYCHOL. BULL. 1, 2 (2006).

111. See Nick Haslam et al., Beliefs About Personality Change and Continuity, 42 PERSONALITY AND INDIVIDUAL DIFFERENCES 1621, 1628 (2007) (concluding that the study "participants' beliefs about the direction of normative adult personality change were reasonably accurate"); see also Anne E. Wilson \& Michael Ross, From Chump to Champ: People's Appraisals of their Earlier and Present Selves, 80 J. PERSONALITY \& SOC. PSYCHOL. 572, 583 (2001) ("people possess implicit theories concerning the mutability of traits. They view some personal characteristics as readily changeable and others as stable" (presumably setting aside the effects of changes in circumstances)) (internal citation omitted).

112. For useful background, see generally JOEL FEINBERG, HARM TO SELF (1989); JOEL FEINBerg, PATERnalism (Rolf Sartorius ed., 1984); JoEl FeInberG, PATERnAlism: THEORY ANd PRACTICE (Christian Coons \& Michael Weber eds., 2013); Emma C. Bullock, A Normatively Neutral Definition of Paternalism, 65 PHIL. Q. 1 (2014); Gerald Dworkin, Paternalism, STANFORd ENCYCLOPEDIA PHIL. (Nov. 6, 2002 rev. ed. June 4, 2014), http://plato.stanford 
right to be forgotten is intended to prevent our imposing unjust harms on other persons by our irrationally failing to discount their past actions, the rule would in that sense not count as paternalistic. In a broader sense though, a right to be forgotten is intended to affect our choices as to whom we associate with, not by providing more information, or through uncontroversial explanation of information, but by depriving us of information, or by raising our costs of obtaining information, based on official fears that we would misinterpret or attach too much weight to that assumedly true information. ${ }^{113}$ This is not an attractive public policy path. In other speech contexts, certainly, the Supreme Court has appreciated the controversy of depriving competent adults of accurate data when making commercial and personal decisions affecting other persons. ${ }^{114}$

One might argue to the contrary that the continuing internet accessibility, ${ }^{115}$ of say a report of a decade-old bankruptcy liquidation, ${ }^{116}$ amounts to misleading speech, ${ }^{117}$ and as misleading speech, it is properly subject to official delinking or deletion, whether paternalistically or not. But it is far from clear that such a report should now count as misleading on the grounds that the debtor's circumstances or character might well have changed in the intervening decade. As we have seen, competent adults typically recognize the possibility of maturation, ${ }^{118}$ as well as, quite obviously, of relevant change of circumstance. To refuse credit, say, to a now objectively creditworthy

.edu/entries/paternalism. For an unusually forthright defense of paternalism in particular circumstances, see SARAH CONLY, AGAINST AUTONOMY: JUSTIFYING COERCIVE PATERNALISM (2013).

113. See sources cited supra note 112. This is presumably true in the case of information that is somehow deemed to be irrelevant to our assumed purposes, or obsolete. See supra note 6 and accompanying text.

114. See, e.g., Linmark Assocs. v. Twp. of Willingboro, 431 U.S. 85, 97 (1977) (quoting Va. Pharmacy Bd. v. Va. Citizens Consumer Council, 425 U.S. 748, 770 (1976)); Thompson v. Western States Med. Ctr., 535 U.S. 357, 375 (2002); Riley v. Nat'l Fed. of the Blind, 487 U.S. 781, 79091 (1988); Meese v. Keene, 481 U.S. 465, 481-82 (1987).

115. Realistically, there is of course a practical difference between convenient and nearly universal internet accessibility, and the merely formal accessibility of unique local paper records, or computer files open only to authorized personnel.

116. Cf. Case C-131/12, Google Spain SL v. Agencia Española de Protección de Datos, Mario Costeja González (May 13, 2014), available at http://curia.europa.eu (citing Council Directive 95/46, arts. 2, 4, 7-9, 14, 1995 O.J. (L 281) (EC)).

117. See ITT Cont'l. Baking Co. v. FTC, 532 F.2d 207, 207 (2d Cir. 1976) (determining whether product advertisements for Wonder Bread were misleading).

118. See supra note 111 and accompanying text. When all else is, or appears to be, entirely equal, some persons might systematically prefer to trust someone with no bankruptcy over someone with a stale bankruptcy experience. Persons with arguably stale adverse experiences, though, need not passively assume that all else must remain perpetually equal. To complicate 
person, is to leave money on the table, and to thereby invite one's competitors to take advantage of our own irrationality.

Further, an accurately dated but arguably stale bankruptcy report is clearly not misleading in the sense that, say, a carrot seller's triumphant claim that her particular carrots are cholesterol-free would be. ${ }^{119}$ The decision makers in right to be forgotten cases will inevitably face an endless succession of assertions that a particular representation is now misleading, for whatever purposes might be imaginable or actually imagined, across the broadest range of specific circumstances. Such a succession of speculative cases would also require the decision makers to somehow classify the allegedly misleading internet speech at issue as either commercial speech or non-commercial speech, ${ }^{120}$ assuming that misleading commercial speech can be somewhat more freely regulated than social or political speech broadly defined. ${ }^{121}$

As it has thus far been conceived, a broad right to be forgotten involves distinctive practical problems associated with a substantial element of government paternalism. Such an argument could easily be further developed. ${ }^{122}$ The main focus of this article, however, has instead been on the range of relevant and mutually reinforcing biases and asymmetries, and on related practical considerations more generally. Each of the reinforcing practical concerns raised above adds further pragmatic complications, particularly to the operation of any broad-sweeping, generalized right to be forgotten.

At an extreme though, even pragmatic concerns for the risks, costs, and sheer workability of any broad legal mechanism unavoidably

matters, we might factor in the possible attractiveness to some potential new creditors of a person who has only recently discharged their debts in bankruptcy. See, e.g., Applicant Bankruptcy on Credit Report, YOUCHECKCREDIT.COM, www.youcheckcredit.com/blog/2012/07 (last visited Mar. 12, 2015).

119. This example assumes that, without distinction among carrot producers, no carrots contain cholesterol. See Nina K. Hauptman, Carrots and Cholesterol, LIVESTRONG.COM (Jan. 30, 2014), http:/ /www.livestrong.com/article/292060-carrots-cholesterol/.

120. See generally Thompson v. Western States Med. Ctr., 535 U.S. 357 (2002) (determining commercial speech restrictions for certain pharmaceutical advertisements are unconstitutional); R. George Wright, The Openness of the Commercial Speech Test and the Value of Self-Realization, 88 U. DET. MERCY L. REV. 17 (2011) (arguing that a reasonableness test for commercial speech would promote self-realization).

121. See Wright, supra note 120; R. George Wright, Electoral Lies and the Broader Problems of Strict Scrutiny, 56 FLA. L. REV. 759, 784-87 (2012). It is also unclear how much policy weight should be accorded to any internet posting that does not rise to the level of speech on a matter of public interest or concern. See sources cited supra note 73.

122. See the preferred counterspeech or "more speech" remedy for allegedly bad speech championed by Justice Brandeis in Whitney v. California, 274 U.S. 357, 372, 377 (1927) (Brandeis, J., concurring), overruled on other grounds by Brandenburg v. Ohio, 395 U.S. 444 (1969). 
begin to merge with fundamental relevant moral and political principles. Dystopias, in the extreme case, may manifest as systematic and mutually reinforcing biases, severe asymmetries of information and motivation, and policy distortions and inefficiencies. Any such political or moral concern may seem irrelevant if we simplistically think of a right to be forgotten as the merely straightforward universal empowerment of individuals, and perhaps of small groups. ${ }^{123}$ But for every individual who is empowered by a legally enforced cleaning of the personal internet slate, many other individuals, disproportionately those who cannot easily afford the most productive internet searches, ${ }^{124}$ may lose realistic access to usable information without their knowledge or consent.

One might argue in response that the lost information was authoritatively deemed to be outdated or irrelevant, ${ }^{125}$ at least for such purposes as the relevant decision maker was able to envision. It is unnecessary to reiterate the systematic biases and asymmetries that predictably tend to distort such determinations. Rather, the primary concern is that determining which items of information should be widely accessible is made not by an empowered individual, but, ultimately, by a government or a court that sets the criteria for search engine corporations and other private actors to follow. It is certainly worth considering society's comfort with a for-profit entity like Google making discretionary public policy decisions. However, if the corporate decision rules are ultimately set in general terms by governments, it is unclear that individual persons are thereby distinctly empowered.

In the end, it is certainly understandable that contemporary Europeans in particular, given the history of the twentieth century, would be especially anxious about personal privacy. ${ }^{126}$ But it is far from clear why the best response to nightmarish historic centralized governmental abuse of privacy is to entrust decisions as to the relevance and

123. Whether and how any broad personal right to be forgotten should be extended to groups, large or small, and to various sorts of corporate entities, will be left to defenders of such a right.

124. See sources cited supra note 75 .

125. See generally supra Part II.

126. See Craig Timberg \& Michael Birnbaum, In Google Case, E.U. Court Says People Are Entitled to Control Their Own Online Histories, WASH. POST (May 13, 2014), http://www .washingtonpost.com/business/technology/eu-court-people-entitled-to-control-own-online -histories/2014/05/13/8e4495d6-dabf-11e3-8009-71de85b9c527_story.html. 
significance of information, in unforeseen contexts, to a few multinationals, and ultimately to centralized governments. ${ }^{127}$ It seems more reasonable to entrust such decisions to the various people who may be affected, positively or negatively, by how sensibly they respond to and discount the information in question. ${ }^{128}$ The exercise of discretionary authority to grant or withhold access to information, whether by one or more international profit-seeking entities or by centralized governments, where it is not systematically skewed as described above, may well tend to track the perceived interests of that decision maker. Those interests may not correspond to the interests of affected individuals or the broader public. ${ }^{129}$

\section{CONCLUSION}

The idea of a broad-sweeping right to be forgotten, in whatever form it is proposed, inevitably raises fundamental questions. It is tempting to try to make sound, broad legal policy by somehow pitting the value of informational privacy, however defined, against an equally vague and general right of access to information itself. A debate at that level of competing abstract rights, however, distorts the issues without encouraging genuine progress in understanding.

The approach taken in this Article has focused on the systematic and mutually reinforcing patterns of biases and asymmetries likely, in practice, to distort, in predictable ways, the practical operation of any version of a generalized right to be forgotten. Some of the crucial biases and asymmetries reflect familiar psychologies, cognitive limits, incentives, and patterns of interests of persons and institutions, as

127. See id. For a discussion of extreme cases of government control of decisions as to the obsolescence or irrelevance of information, see VIKTOR MAYER-SCHONBERGER, DELETE: THE VIRTUE OF FORGETTING IN A DigITAL AGE 120-21 (rev. ed. 2009). See also GEORGE ORWELL, 1984204 (Harcourt Brace Javanovich Inc. ed., Penguin Books 1983) (1949) ("'[w]ho controls the past controls the future; who controls the present controls the past'").

128. See supra note 111 and accompanying text. For the inevitable dispersal of knowledge about relevance, risks, discounting, and value, see sources cited supra note 74 .

129. One of the developers of the World Wide Web has recently spoken of potential corporate and governmental abuses. See Matthew Sprakes, Sir Tim Berners-Lee: World Needs an 'Internet Magna Carta,' TELEGRAPH (Sept. 29, 2014 at 10:43 AM), http://www.telegraph.co.uk/ technology/news/11127557/Berners-Lee-world-needs-an-internet-Magna-Carta.html ("[s]uddenly the power to abuse the open internet has become so tempting both for government and big companies"). Note, as one potential avenue for future abuse, that Google "regularly receives requests from government agencies and courts around the world to remove content from Google products." Google Transparency Report, GOOGLE, www.google.com/ transparencyreport/removals/government (last visited May 20, 2015). 
recognized in common experience and supported by the available social science evidence. On this basis, this Article has instead recommended a range of better understood, fine-tuned, particularized, and more contextualized common law and statutory privacy-oriented remedies, as continually amended in the interests of socio-economic fairness and equality. Given this more attractive alternative path, a broadly generalized right to be forgotten should be subject to a recall. 
